International Journal of English Language Studies (IJELS)

ISSN: 2707-7578

DOI: $10.32996 /$ ijels

Website: https://al-kindipublisher.com/index.php/ijels

\title{
Request Strategies and Gender Differences among Bangladeshi Students within Online Classrooms
}

Shafinaz Sikder 8 (D)

Lecturer, Department of English, University of Scholars, Bangladesh

$\bowtie$ Corresponding Author: Shafinaz Sikder, E-mail: shafinaz.4789@gmail.com

\author{
ARTICLE INFORMATION \\ Received: August 08, 2021 \\ Accepted: September 02, 2021 \\ Volume: 3 \\ Issue: 9 \\ DOI: 10.32996/ijels.2021.3.9.1
}

\section{KEYWORDS}

Request strategies, online classrooms, students, gender, polite

\section{ABSTRACT}

This research tried to identify the type of requests made by the students within a few Bangladeshi online classrooms. The study also aimed at focusing on possible gender differences between the students based on the requests they made. It adopted the research method used by Onem (2016), who investigated how men and women make requests and observed how they differ in the case of being polite and showing directness. Since there have been no previous studies conducted like this before, this paper analysed and categorized the types of requests by addressing the research gap. The theoretical framework relied on the Cross-Cultural Speech Act Realization Project (CCSARP), outlined by Blum-Kulka and Olshtain (1984). Three video records of online classes of "London School of English, Keraniganj, Dhaka, Bangladesh" were undertaken as the main data which was observed naturally followed by analysis and interpretation. The data analysis framework was also undertaken from the CrossCultural Speech Act Realization Project (CCSARP) theory by Blum-Kulka and Olshtain (1984). To analyse the data gathered from the videos, a particular coding scheme of (CCSARP) was used. The result obtained showed that the female students made around $62.5 \%$ requests while the male students did only around $37.5 \%$. The requests made by the female students were not only significantly higher but they were more polite than the males. Therefore, this small-scale study is expected to help teachers and both male and female students improve their communication skills. The types of requests identified in this study might help students of both genders become aware of their request-making techniques and help the researchers understand the process of request-making in the students' minds.

\section{Introduction}

\subsection{Research Background}

Research on speech acts such as requests (Jalilifar 2009, Elmianvari \& Kheirabadi 2013) has been very popular in the field of pragmatics due to its frequent occurrence within a daily conversation. It is also one of the most produced utterances in second language classrooms (Thuruvan, 2017, p. 213), where male and female students behave differently due to the stereotypical gender roles. In other words, requests are speech acts where although the students are of the same age and the same status, their use of language and pragmatic behaviour in the classroom becomes different (Haas, 1979b, as cited in Onem, 2016, p. 13).

Like other Asian countries and cultures, Bangladesh is also very particular when it comes to the gender issue and the girls and the boys are far different from each other, especially when asking for a favour. For example, it is believed that Bangladeshi female students tend to be extremely polite and avoid face-threatening acts at all costs when talking to their teachers, as described by Onem (2016). However, there are also studies (like Alakrash, 2020) claiming that the request-making strategies by male students are equally polite when directed toward teachers. The different outcomes of these studies interested the

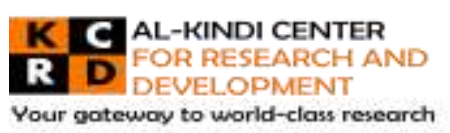

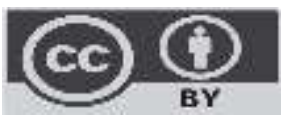

Published by Al-Kindi Center for Research and Development. Copyright (c) the author(s). This open access article is distributed under a Creative Commons Attribution (CC-BY) 4.0 license 
researcher of this study to investigate whether and how different the request strategies are in respect to the students' gender roles.

Therefore, the present study aims at identifying the type of requests made by the students within a few Bangladeshi online classrooms. The study also aims at focusing on possible gender differences between the students based on the requests they made.

\subsection{Research Questions}

a) What types of requests are made by Bangladeshi students within the online classrooms?

b) Are there any differences between Bangladeshi male and female students in case of making requests?

\subsection{Research Significance}

The study by Onem (2016) took the initiative to investigate how men and women make requests and observed how they differ in the case of being polite and showing directness. Therefore, this present study will also consider a similar approach. Moreover, a few studies are analysing and categorizing the types of requests in Bangladesh and to the best knowledge of the researcher, this particular type of study has not been conducted within Bangladeshi online classrooms. Therefore, this study attempts to initiate future researchers to understand the relationship between the genders and making requests.

\section{Literature Review}

\subsection{Requests and Gender}

"Requests" occur when one takes the risk of losing his/her face, Ardissono et al., (1999). According to Brown and Levinson (1978), prior to a speech act, a speaker calculates the possible outcomes and then requests at the potential expense of taking the risk of losing face.

Requests are therefore believed to be influenced by many variables, especially by gender. Holmes and Stubbe (2003) presented a feminine speech as indirect and male speech as direct (p. 574). Similarly, Thimm et al. (2003) said that females used significantly more indirect requests while males preferred direct requests (p. 544).

\subsection{Previous Studies on Requests and Gender Differences}

There is much previous research on the language choice of males and females. As found in (Haas, 1979a), men are more directive, while women are more polite and expressive when making requests. Onem (2016) also found something similar; women tend to make a very detailed request while men tend to stick to the point. Furthermore, studies were carried out to investigate Turkish requests like Bikmen and Martı, 2013; Tabar, 2012 etc., which also yielded similar results. To sum up, it can be said that women tend to place more value on making connections and seeking involvement while making requests and men try to make it brief and straightforward (Onem, 2016, p.34).

\subsection{Requests and English Medium Classrooms}

Apart from the issue of differences between male and female students, other studies like Canale, (1983) and Kurdghelashvili (2015) confirmed that having only linguistic competence is insufficient for learners to understand 'classroom-based pragmatics' in a foreign tongue. Therefore, students need to have pragmatic competency which is defined as the students' use of politeness in speech acts (such as requests) for understanding each other well in a given classroom context which is usually influenced by variables like gender (Koike, 1989).

\section{Research Methodology}

\subsection{Theoretical Framework}

The theoretical framework of this study was based on the Cross-Cultural Speech Act Realization Project (CCSARP) framework, outlined by Blum-Kulka and Olshtain (1984). This is because well-known studies like Biesenbach-Lucas (2007), Jalilifar (2009) etc. considered this framework their fundamental guide. Also, because the criteria suggested in this framework were quite applicable in Asian settings like that of Turkey; therefore, it also seemed to be appropriate in the case of Bangladeshi contexts.

\subsection{Data Type and Source}

Three video records of online classes of "London School of English, Keraniganj, Dhaka, Bangladesh" (see appendix 1) were undertaken as the main data downloaded from YouTube. 
Following is a table showing the details about the students and the online classes:

Table 1: Students and Online Class Details

\begin{tabular}{|c|c|c|c|c|c|c|}
\hline $\begin{array}{c}\text { Total Classes } \\
\text { \& Content }\end{array}$ & $\begin{array}{c}\text { Total Class } \\
\text { Duration }\end{array}$ & $\begin{array}{c}\text { Number of } \\
\text { Students }\end{array}$ & $\begin{array}{c}\text { Male } \\
\text { Students }\end{array}$ & $\begin{array}{c}\text { Female } \\
\text { Students }\end{array}$ & $\begin{array}{c}\text { Education } \\
\text { Level }\end{array}$ & $\begin{array}{c}\text { Students Age } \\
\text { Group }\end{array}$ \\
\hline $\begin{array}{c}\text { Class no. } 1 \\
\text { Grade-5, } \\
\text { (History) }\end{array}$ & $21: 36$ mins & 9 & 5 & 4 & Elementary & 7 \\
\hline $\begin{array}{c}\text { Class no. 2 } \\
\text { Grade 3, } \\
\text { (General } \\
\text { Science) }\end{array}$ & $\begin{array}{c}28: 24 \\
\text { mins }\end{array}$ & 8 & 3 & 5 & Elementary & 5 \\
\hline $\begin{array}{c}\text { Class no. 3 } \\
\text { Grade 4, } \\
\text { (English } \\
\text { Literature) }\end{array}$ & $\begin{array}{c}26: 01 \\
\text { Mins }\end{array}$ & 8 & 4 & 4 & Elementary & 6 \\
\hline Total & 75 minutes & 25 & 12 & 13 & & \\
\hline
\end{tabular}

This data was particularly selected to address the pragmatic issues within the newly set online classrooms due to the Covid 19 pandemic. Elementary students in Bangladesh never did classes in digital platforms and therefore were having some trouble understanding the technical part itself. Apart from this, there were problems related to the teachers' understanding of feedback, which were usually explained on blackboards within a traditional classroom before the pandemic. Also, there were internet connection disruptions taking place, for which the students had to make different requests from time to time. These videos were thus selected to address all these request strategies performed to solve the problems and understand the classes.

\subsection{Data Collection Procedure}

The data collection was done by the observation of naturally occurring interactions in the online classrooms. As all of them were video recordings, provided tangible evidence of data use

\subsection{Data Analysis Procedure}

For addressing research question one, extracts with request acts were obtained. The data was then classified, interpreted, and analysed in conversation extracts through verbatim transcription (refers to the word-for-word reproduction of verbal data, where the written words are an exact replication of the audio recorded words, Poland 1995). Apart from this, as all the students attempted to talk in English within the online classrooms, the recordings were not translated.

For addressing research question two, the frequency and percentages of the total requests was calculated and compared according to the gender of the participants.

The data was analysed and discussed based on the Cross-Cultural Speech Act Realization Project (CCSARP) theory by Blum-Kulka and Olshtain (1984). To analyse the data gathered from the videos, the particular coding scheme of (CCSARP) was used. CCSARP framework indicated three levels of directness: direct level requests, conventionally indirect requests and non-conventionally indirect requests (as described in Blum-Kulka, et al. 1984). Blum-Kulka, et al. (1984) showed a combination of the level of directness and strategy types in CCSARP project as follows:

Request Categories Proposed by Blum-Kulka (1984, p. 133)

\section{Descriptive Category \& Examples}

\section{Direct level}

\section{Mood Derivable}

Grammatical mood of the verb in the utterance marks its illocutionary force as a request.

e.g Clean up the kitchen.

\section{Performative}

Illocutionary force of the utterance is explicitly named by the speakers.

e.g I'm asking you to move your car. 


\section{Hedged Performative}

Utterances embedding the naming of the illocutionary force.

e.g I would like to ask you to move your car.

\section{Obligation statement}

Illocutionary point is directly derivable from the semantic meaning of the locution.

e.g You'll have to move your car.

\section{Want statement}

The utterance expresses the speaker's intentions, desires or feelings vis-à-vis the fact that the hearer do X.

e.g I would like you to clean the kitchen.

\section{Conventionally Indirect}

\section{Suggestive Formulae}

The sentence contains a suggestion to $X$.

e.g. How about cleaning up?

\section{Query Preparatory}

Utterance contains a reference to preparatory conditions (e.g. ability or the possibility of the act being performed) as conventionalized in any specific language.

e.g Could you clean up the mess in the kitchen?

\section{Non-conventionally indirect level}

8. Strong hints: Utterances containing partial reference to object needed for the implementation of the act

e.g. The game is boring.

9. Mild hints: Utterances that make no reference to the request but are interpretable as requests by context

e.g. We've been playing this game for over an hour now.

\section{Findings \& Analysis}

\subsection{Identification of Request Strategies}

The request strategies and the degree of directness in each utterance were compared to the CCSARP coding scheme of BlumKulka and Olshtain (1984). Following are the identification of the types of requests along with examples from the extracts made by the male and female students within the online classrooms:

Table 2: Identification of Request Strategies

\begin{tabular}{|c|c|c|c|c|}
\hline Extracts & $\begin{array}{l}\text { Gender of } \\
\text { Students }\end{array}$ & Type of Request & $\begin{array}{l}\text { Descriptive } \\
\text { Category }\end{array}$ & Examples from three Online Classes \\
\hline 1 & Female & Conventionally Indirect & $\begin{array}{c}\text { Query } \\
\text { Preparatory }\end{array}$ & $\begin{array}{l}\text { Hi Rashid, could you read the homework } \\
\text { for teacher? }\end{array}$ \\
\hline 2 & Female & $\begin{array}{l}\text { Non-Conventionally } \\
\text { Indirect }\end{array}$ & Mild Hints & $\begin{array}{c}\text { Yes teacher, yes... we were doing task } 2 \\
\text { through the week }\end{array}$ \\
\hline 3 & Male & $\begin{array}{l}\text { Non-Conventionally } \\
\text { Indirect }\end{array}$ & Strong Hints & $\begin{array}{l}\text { Teacher, I could not do it teacher. Lesson } \\
3 \text { reading passage is hard. }\end{array}$ \\
\hline 4 & Female & Conventionally Indirect & $\begin{array}{l}\text { Query } \\
\text { Preparatory }\end{array}$ & $\begin{array}{c}\text { Teacher, can you say it again? sorry } \\
\text { teacher. }\end{array}$ \\
\hline 5 & Female & Conventionally Indirect & $\begin{array}{l}\text { Suggestive } \\
\text { Formulae }\end{array}$ & Tasnim, wait.. lets read it again? \\
\hline 6 & Male & Direct Level & Mood Derivable & No, you read it to teacher. \\
\hline
\end{tabular}




\begin{tabular}{|c|c|c|c|c|}
\hline 7 & Female & Conventionally Indirect & $\begin{array}{c}\text { Query } \\
\text { Preparatory }\end{array}$ & $\begin{array}{l}\text { Ok.. so can you remove it and write the } \\
\text { correct answer? }\end{array}$ \\
\hline 8 & Male & Conventionally Indirect & $\begin{array}{l}\text { Suggestive } \\
\text { Formulae }\end{array}$ & So lets form the group again \\
\hline 9 & Male & Direct Level & Performative & $\begin{array}{l}\text { No, its your turn. I am the group leader. I } \\
\text { am asking you to share the task with her. }\end{array}$ \\
\hline 10 & Male & Direct Level & $\begin{array}{c}\text { Hedged } \\
\text { Performative }\end{array}$ & $\begin{array}{l}\text { Ok teacher...I have a question...I would } \\
\text { like to ask you something..about what we } \\
\text { need to study for the next class? }\end{array}$ \\
\hline 11 & Female & Conventionally Indirect & $\begin{array}{c}\text { Query } \\
\text { Preparatory }\end{array}$ & $\begin{array}{l}\text { Thank you teacher, but could you please } \\
\text { give us more time so that we finish it all? }\end{array}$ \\
\hline 12 & Female & Conventionally Indirect & $\begin{array}{l}\text { Suggestive } \\
\text { Formulae }\end{array}$ & $\begin{array}{l}\text { No teacher,..not really, how about putting } \\
\text { 'have' with 'she'? }\end{array}$ \\
\hline 13 & Female & Conventionally Indirect & $\begin{array}{c}\text { Query } \\
\text { Preparatory }\end{array}$ & $\begin{array}{l}\text { Teacher, excuse me, can you please tell } \\
\text { how to write it? }\end{array}$ \\
\hline 14 & Male & Direct Level & Performative & $\begin{array}{l}\text { Yes, I say so.I will submit the copy and I } \\
\text { want to you do the rest. }\end{array}$ \\
\hline 15 & Female & Conventionally Indirect & $\begin{array}{c}\text { Query } \\
\text { Preparatory }\end{array}$ & No you..please can you give any example? \\
\hline 16 & Female & Conventionally Indirect & $\begin{array}{l}\text { Suggestive } \\
\text { Formulae }\end{array}$ & $\begin{array}{l}\text { Lets do the grammar part first, it is section } \\
\text { two, fill in the gaps. }\end{array}$ \\
\hline
\end{tabular}

The above table shows that the female students used mainly conventionally indirect requests which fall under the query preparatory category. A few of the male students made "direct" requests where they used performatives and mood derivable occasionally.

\subsection{Discussion in Light of Research Question 1}

Considering research question one on the types of requests made within the online classrooms, it can be said that the type of requests mainly seen are 'conventionally indirect requests' under which the preparatory query category was the most common one. For example, the utterance on 'can you please tell how to write it?' has been asked as in to request the teacher to tell how to write and was therefore used with 'please' and 'can'; instead of only saying "tell me how to write it". According to Brown \& Levinson (1987), students tend to employ the conventionally indirect request to appear more polite when making requests to teachers (as cited in Thuruvan, 2017).

Again, there were uses of mood derivable like "no you read it to teacher" that acted as an illocutionary force used while making request to a classmate by another one. According to Thuruvan (2017), these sorts of utterances might seem like a random statement, but the mood attached is understood by the hearer as a request (p. 213). This, according to Brown and Levinson (1987) is "less polite than indirect levels" however it was acceptable in the context because both the speaker and the hearer are classmates and they possibly share a similar level of social status and position (as suggested by Thuruvan, 2017, p. 214).

In gist, the findings are similar to that of Thuruvan's (2017) study, which showed that students seem to be less polite while making requests to their friends and more polite while making requests to teachers. This is because, like other Asian cultures, Bangladeshis also are expected to show more respect to teachers and therefore remains indirect while making requests to them.

\subsection{Gender Differences in Request Strategies}

Apart from investigating the types of request strategies, the study also looked at how the male and female students differed in case of making requests. The following table shows a statistically significant difference between the male and female students: 
Table 3: Frequency and Percentage of Request Strategies by Gender

\begin{tabular}{|c|c|c|}
\hline Categories of Requests & Female Students & Male Students \\
\hline Query Preparatory & 6 & 1 \\
\hline Suggestive Formulae & 3 & 1 \\
\hline Mood Derivable & 0 & 0 \\
\hline Mild Hints & 1 & 1 \\
\hline Strong Hints & 0 & 1 \\
\hline Hedge Performatives & 0 & 2 \\
\hline Performatives & $02.5 \%$ & 6 \\
\hline Total Requests & & \\
\hline
\end{tabular}

The above table shows that the female students made around $62.5 \%$ requests while the male students did only around $37.5 \%$ within the online classrooms. The requests made by the female students were not only significantly higher, but they were more polite than the males. For example, most females stick to conventionally indirect strategies that belong to the query preparatory and suggestive formulae category while the males mainly use the performatives that fall under the direct level. The females avoided using mood derivable, performatives or even hedge performatives, while the males did not use a single query preparatory type of request in the classrooms.

\subsection{Discussion in Light of Research Question 2}

Considering the research question two, in the light of the above findings, it can be said that there is a significant difference between Bangladeshi male and female students in case of making requests. To state it briefly, in terms of the language, men used more directives and women used more supportive and polite terms while making requests to the teacher and within themselves (as stated in Onem, 2016, p. 14).

In other words, the results of the data analysis showed that females were not only polite and but also indirect with their requests and did the maximum number of request acts while asking for a favour in the classrooms. Such a way to make a request might be regarded as a social or cultural support strategy assigned to the females specially to avoid losing face (Al-Marrani \& Sazalie, 2010). The result can also be traced to Al-Marrani \& Sazalie (2010) who examined the request strategies by Yemen's male and female speakers. It was found that the directness was realized by means of mood derivable strategy and conventional indirectness was mostly realized by means of query preparatory as both the males and females were assigned to particular gender roles.

\subsection{Limitations of the Study}

This study was limited to only three Bangladeshi online classrooms recordings of a single school. Also, there were a few request acts exchanged among the students. Moreover, the age groups of the students were similar, so the result cannot be made generalized because if the age group were diverse, the result would also be different. 


\section{Conclusion}

Research on the speech act of requests is very little in the context of English medium schools of Bangladesh. This study tried to explore what type of request strategies is commonly made and whether it varies according to the gender of the students. Interestingly the result obtained can be related to other studies carried out in different contexts and cross-culturally, although the Bangladeshi context is quite different from other countries. Thus, this small-scale study is expected to add to the existing data on the request strategies, which might help teachers and both male and female students to improve their communication skills. The types of requests identified in this study might help students of both genders become aware of their request-making techniques and help the researchers understand the process of request-making in the students' minds. As recommended by Thuruvan (2017), the level of directness or indirectness deemed appropriate from this study may be explicitly taught in the online classrooms, based on the students' level, to facilitate better communication.

\section{References}

[1] Alakrash, H. M., \& Bustan, E. S. (2020). Politeness Strategies Employed by Arab EFL And Malaysian ESL Students in Making Request. Social Sciences, 10(6), 10-20.

[2] Al-Marrani, Y. M. A., \& Sazalie, A. (2010). Polite request strategies by male speakers of Yemeni Arabic in male-male interaction and malefemale interaction. The International Journal of Language Society and Culture, 63.

[3] Ardissono, L., Boella, G., \& Lesmo, L. (1999). Politeness and speech acts. In Proc. Workshop on Attitude, Personality and Emotions in UserAdapted Interaction (pp. 41-55).

[4] Blum-Kulka, S. \& Olshtain, E. (1984). Requests and apologies: A cross-cultural study of speech act realization patterns CCSARP. Applied Linguistics. Vol. 5, 196.

[5] Brown, P., \& Levinson, S. (1978). Universals of language use: Politeness phenomena. In E. Goody (Ed.), Questions and Politeness (pp. 56-324). Cambridge: Cambridge University Press

[6] Brown, P., Levinson, S. C., \& Levinson, S. C. (1987). Politeness: Some universals in language usage (Vol. 4). Cambridge university press.

[7] Haas, A. (1979a). Male and female spoken language differences: Stereotypes and evidence. Pschological Bulletin, 86(3), 616-626.

[8] Haas, A. (1979b). The acquisition of genderlect. In J. Orasnu, M. Slater, \& L. Adler (Eds.), Language, Sex and Gender: Does la différence make a difference? (Vol. 327, pp. 101-113).

[9] Holmes, J., \& Stubbe, M. (2003). "Feminine workplaces": Stereotype and reality. In J.

[10] Jalilifar, A. (2009). Request Strategies: Cross-Sectional Study of Iranian EFL Learners and Australian Native Speakers. English language teaching, 2(1), 46-61.

[11] Koike, D.A. (1989). Pragmatic competence and adult L2 acquisition: Speech acts in interlanguage. The Modern Language Journal, 73(3), 279289.

[12] Önem, E.E. (2016). A study on gender differences in the length of requests in Turkish. Journal of Language and Linguistic Studies, 12(2), 1321.

[13] Spolsky, B. (1998). Sociolinguistics. Oxford: Oxford University Press.

[14] Thimm, C., Koch, S. C., \& Schey, S. (2003). Communicating gendered professional identity: Competence, cooperation, and conflict in the work place. In J. Holmes, \& M. Meyerhoff (Eds.), The Handbook of Language and Gender (pp. 528-549). MA, USA: Blackwell Publishing.

[15] Thuruvan, P., \& Yunus, M. M. (2017). The speech act of request in the ESL classroom. 3L: Language, Linguistics, Literature ${ }^{\circledR}$, 23(4).

\section{Appendix 1: Online Class Sources \& Extracts with Examples of Request Strategies}

1) Class no.1, Grade 5: 24th June, 2020, History class taken by Shanchitta Mridha Setu. https://www.youtube.com/watch?v=PaEgwMSWojo\&t=36s

2) Class no. 2, Grade 3: 25th June, 2020, General Science class taken by Jannatul Ferdush. https://www.youtube.com/watch?v=R4aWQPnVatk

3) Class no. 3, Grade 4: 16th August 2020, English Literature taken by Asha Barman https://www.youtube.com/watch?v=mju2iDEwCsw

\begin{tabular}{|c|c|}
\hline Extracts & Examples from Three Online Classes \\
\hline Class no. 2, grade 3 & Hi Rashid, could you read the homework for teacher? (3:06) \\
\hline Class no. 2, grade 3 & $\begin{array}{c}\text { Yes teacher, yes... we were doing task 2 through the week } \\
\text { (19:54) }\end{array}$ \\
\hline Class no. 1, grade 5 & $\begin{array}{c}\text { Teacher, I could not do it teacher. Lesson 3 reading passage } \\
\text { is hard (27:02). }\end{array}$ \\
\hline Class no. 2, grade 3 & Teacher, can you say it again? sorry teacher. (13:32) \\
& \\
\hline
\end{tabular}




\begin{tabular}{|c|c|}
\hline Class no. 3 , grade 4 & Tasnim, wait.. lets read it again?(17:21) \\
\hline Class no. 2 , grade 3 & No, you read it to teacher. (11:12) \\
\hline Class no. 2 , grade 3 & $\begin{array}{l}\text { Ok.. so can you remove it and write the correct } \\
\text { answer?(15:21) }\end{array}$ \\
\hline Class no. 3 , grade 4 & So lets form the group again (08:21) \\
\hline Class no. 3 , grade 4 & $\begin{array}{l}\text { No, its your turn. I am the group leader. I am asking you to } \\
\text { share the task with her.(07:30) }\end{array}$ \\
\hline Class no. 1 , grade 5 & $\begin{array}{l}\text { Ok teacher,..I have a question...I would like to ask you } \\
\text { something...about what we need to study for the next } \\
\text { class?(5:21) }\end{array}$ \\
\hline Class no. 1 , grade 5 & $\begin{array}{l}\text { Thank you teacher, but could you please give us more time } \\
\text { so that we finish it all? (3:12) }\end{array}$ \\
\hline Class no. 2, grade 3 & $\begin{array}{l}\text { No teacher,..not really, how about putting 'have' with } \\
\text { 'she'?(4:37) }\end{array}$ \\
\hline Class no. 3 , grade 4 & $\begin{array}{l}\text { Teacher, excuse me, can you please tell how to write } \\
\text { it?(6:32) }\end{array}$ \\
\hline Class no. 1 , grade 5 & $\begin{array}{l}\text { Yes, I say so.I will submit the copy and I want to you do the } \\
\text { rest.(4:50) }\end{array}$ \\
\hline Class no. 1 , grade 5 & No you..please can you give any example?(2:30) \\
\hline Class no. 2, grade 3 & $\begin{array}{l}\text { Lets do the grammar part first, it is section two, fill in the } \\
\text { gaps. (9:37) }\end{array}$ \\
\hline
\end{tabular}

